\title{
PEDOARCHEOLOGICAL RESEARCH OF THE ZHAYYK-1 KURGAN ${ }^{1}$
}

\author{
Maxim V. Eltsov \\ Institute of Physicochemical and Biological Problems in Soil Science of the Russian Academy of Sciences, \\ Pushchino, Russian Federation
}

\begin{abstract}
The article reveals the results of pedoarchaeological research of the Zhayyk-kurgan. The research is based on the pedoarchaeological method in the study of historical monuments as a part of natural. The essence of this method is a joint study of modern soils and ancient paleosols of different age archaeological monuments. The obtained data allowed us to clarify the construction features of the archaeological monument's ground mound, as well as to suggest the time of its building. Natural conditions in this period (probably $5^{\text {th }}$ century BC) were generally similar to modern ones, the area was dominated by steppe landscapes with dark chestnut soils. The central part of the kurgan was built of soil blocks, which are cut out upper humus horizons of the soil in their natural composition. The inner mound of the monument is surrounded by a circular moat about $80 \mathrm{~cm}$ deep. In the central part of the mound, there are traces of burning in the form of burnt and melted blocks, pieces of soil colored brick and dark pink, charred fragments of wood. The internal structure made of blocks is covered with an embankment of yellow-gray loose humus loam, which is a layer of soil lying under the humus horizon in the areas of building blocks preparation, and this material also fills the ring moat. The embankment that overlaps the primary structure, in turn, is covered with a massive gray-brown top-up that forms the appearance of the monument. It is possible to point out three stages of the kurgan construction: the moment of building a block structure with a ring moat; the stage of building the first mound, and then covering the entire structure with the mound of the last burial.
\end{abstract}

Key words: archaeological soil science, paleosols, early iron age, Sauromatian culture, humus blocks.

Citation. Eltsov M.V., 2020. Pedoarcheological Research of the Zhayyk-1 Kurgan. The Lower Volga Archaeological Bulletin, vol. 19, no. 1, pp. 285-293. (in Russian). DOI: https://doi.org/10.15688/nav.jvolsu.2020.1.16

УДК 631.48:930.26

Дата поступления статьи: 19.03.2020

ББК 40.3

Дата принятия статьи: 29.04.2020

\section{ПОЧВЕННО-АРХЕОЛОГИЧЕСКИЕ ИССЛЕДОВАНИЯ КУРГАНА ЖАЙЫК-1 ${ }^{1}$}

\author{
Максим Витальевич Ельцов \\ Институт физико-химических и биологических проблем почвоведения РАН, \\ г. Пущино, Российская Федерация
}

\begin{abstract}
Аннотация. Статья посвящена результатам почвенно-археологических исследований кург. Жайык-1. В основу исследования положен почвенно-археологический метод в изучении памятников истории как памятников природы. Суть данного метода состоит в совместном изучении современных почв и древних палеопочв разновозрастных археологических памятников. Полученные сведения позволили уточнить конструкционные особенности насыпи археологического памятника, а также сделать предположения о времени его создания. Природные условия в этот период - вероятно, V в. до н.э. - в целом были аналогичны современным, в районе господствовали степные ландшафты с темно-каштановыми почвами. Центральная часть кургана была сложена из грунтовых блоков, представляющих собой вырезанные верхние гумусовые горизонты почвы в естественном сложении. Внутренняя насыпь памятника окружена кольцевым рвом глубиною около 80 см. В центральной части кургана присутствуют следы горения в виде обожженных и оплавленных блоков, кусков грунта кирпичного и темно-розового цветов, обугленные фрагменты древесины. Сложенная из блоков внутренняя конструкция перекрыта насыпью из желто-серого рыхлого гумусированного суглинка, представляющего собой слой грунта, залегающего под гумусовым горизонтом на участках заготовки строительных блоков, причем
\end{abstract}


этим материалом также заполнен и кольцевой ров. Насыпь, перекрывающая первичное сооружение, в свою очередь, перекрыта мощной серо-бурой досыпкой, формирующей внешний вид памятника. Можно выделить три стадии постройки кургана: момент создания блочной конструкции с кольцевым рвом; этап создания первой насыпи; последующее перекрытие всей конструкции насыпью последнего захоронения.

Ключевые слова: археологическое почвоведение, палеопочвы, ранний железный век, савроматы, гумусовые блоки.

Цитирование. Ельцов М. В., 2020. Почвенно-археологические исследования кургана Жайык-1 // Нижневолжский археологический вестник. Т. 19, № 1. С. 285-293. DOI: https://doi.org/10.15688/nav.jvolsu.2020.1.16

\section{Введение}

Интеграция археологии с науками естественного направления является отражением общей тенденции развития современного научного знания. В основу настоящего исследования положен почвенно-археологический метод в изучении памятников истории как памятников природы. Суть метода состоит в сопряженном анализе современных и древних погребенных почв разновозрастных археологических памятников, время сооружения которых определяется методами археологии [Демкин, 1997, с. 19].

Почва является совокупным сочетанием всех элементов природной среды (климата, почвообразующей породы, рельефа, растительного и животного мира и др.). Таким образом, каждой природной зоне соответствует свой облик зональной почвы. Современная теория эволюции почв основана на представлении о саморазвитии почв и ландшафтов до состояния динамического равновесия или квазиравновесного состояния с условиями окружающей среды [Таргульян, Александровский, 1976, с. 23]. Развитие почв во времени осуществляется параллельно с изменением факторов почвообразования либо, в силу известной инерционности почвы, под влиянием изменений условий среды в прошлом [Роде, 1984, c. 57; Геннадиев, 1990, с. 12]. Сравнительное изучение почв разновозрастных археологических памятников между собой и с современными почвами позволяет реконструировать изменение палеоэкологических условий во времени.

Были проведены почвенно-археологические исследования кургана Жайык-1, административно расположенного на территории г. Уральска Республики Казахстан. Археологический памятник приурочен к правому высокому берегу р. Урал (Западный Сырт, под- ножье Свистун-горы). Абсолютная высота поверхности составляет 90-95 м. В природном отношении участок исследований относится к зоне сухих степей с типчаково-тонконогоковыльной растительностью. Климат континентальный. Среднегодовая температура воздуха составляет примерно $+6{ }^{\circ} \mathrm{C}$, количество атмосферных осадков около 350 мм в год. Раскопки проводились археологической экспедицией Западно-Казахстанского центра истории и археологии (руководитель экспедиции - научный сотрудник Я.А. Лукпанова). Аналитические лабораторные работы выполнялись по общепринятым методикам [Аринушкина, 1970; Procedures ... , 1995].

\section{Строение и свойства почвенно-грунтовой толщи кургана Жайык-1}

Археологический памятник представляет собой курган высотой в центральной части около 4 м и диаметром насыпи более 40 метров. Курган имеет сложное строение, в значительной мере нарушен грабительскими ямами и перерыт землероями. Время начала сооружения памятника носит дискуссионный характер: в целом, по археологическим данным, относится к савромато-раннесарматскому времени раннего железного века (V-III вв. до н.э.). Центральная часть кургана была сложена из грунтовых блоков, представляющих собой вырезанные верхние гумусовые горизонты почвы в естественном сложении (рис. 1). По периферии внутренняя насыпь окружена кольцевым рвом глубиною около 80 см. В центральной части кургана присутствуют следы горения в виде обожженных и оплавленных блоков, кусков грунта кирпичного и темно-розового цветов, обугленные фрагменты древесины. Сложенная из блоков внутренняя конструкция перекрыта насыпью из желто-серо- 
го рыхлого гумусированного суглинка, представляющего собой слой грунта, залегающего под гумусовым горизонтом на участках заготовки строительных блоков, причем этим материалом также заполнен и кольцевой ров. Насыпь, перекрывающая первичное сооружение, в свою очередь, перекрыта мощной серобурой досыпкой, формирующей внешний вид памятника. В южной части кургана под центральной бровкой прослеживаются следы делювиального сноса материала внутренней конструкции. Возможно, что строение из блоков возводилось этапами и какое-то время находилось без перекрытия, что привело к его частичному разрушению (оплыванию).

Почвенный разрез для изучения погребенной почвы (Ж-1-19) был заложен под центральной частью восточной бровки (восточный фас). Было проведено полевое описание морфологических свойств почвы, выполнены измерения магнитной восприимчивости каппаметром КТ-5 (МВ). Данные по химическим и физико-химическим свойствам погребенной почвы представлены в таблице 1. Профиль «насыпь-погребенная почва» имеет следующее строение: гор. $\mathrm{A}_{\text {кург }}(0-10$ см, гумусовый горизонт почвы внешней насыпи, серо-коричневый легкий суглинок, плитчато-комковатопорошистая структура, уплотнен, сухой; граница ровная; переход заметный по цвету и структуре, МВ 95Х10-6 единиц СИ); гор. В кург (10-38 см, серо-бурый легкий суглинок, неоднородный, структура глыбистая, материал внешней насыпи, границы и переходы резкие,

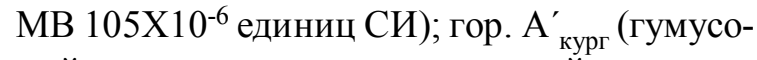
вый горизонт досыпки внутренней конструкции, белесо-желто-серый легкий суглинок плитчато-порошистой структуры, плотный, сухой, граница ровная, переход заметный по цвету и структуре, МВ $121 \times 10^{-6}$ единиц СИ); гор. В' легкий суглинок глыбистой структуры, сухой, плотный, граница ровная, переход резкий, МВ $117 \times 10^{-6}$ единиц СИ); гор. В" 141 см, уплотнен, сухой, конструкция из гумусовых блоков, сильно нарушена землероями, граница ровная, переход резкий, встречаются диагенетические карбонаты, MB $102 \times 10^{-6}$ единиц СИ); гор. А (141-151 см, верхний горизонт погребенной почвы, белесо-серо-коричневый легкий суглинок плитчато-комко- вато-порошистой структуры, сухой, плотный, встречается диагенетический карбонатный налет, граница ровная, переход ясный по цвету и структуре); гор. В (151-166 см, серо-коричневый легкий суглинок; структура призмовидная, непрочная, грани неровные, встречаются гумусированные зоны, граница с затеками, переход заметный); гор. В2са (166181 см, желто-коричневый легкий суглинок, структура призмовидная, грани неровные, затеки гумуса, граница ровная, переход ясный по цвету и появлению карбонатной пропитки); гор. ВС'са (181-193 см, коричнево-желтый легкий суглинок, структура ореховато-призмовидная, карбонатная пропитка при подсыхании, граница ровная, переход ясный по формам выделения карбонатов); гор. ВC"'са (193246 см, темно-желто-бурый легкий суглинок, структура непрочная ореховатая, размер отдельностей около 2 см, грани неровные, слабо отмыты с глинистыми кутанами, свежий, плотный; горизонт аккумуляции карбонатов в виде хорошо оформленной белоглазки размером около 1 см, граница неровная с редким проникновением белоглазки в нижележащий горизонт по корням растений); гор. Сса (246330 см, темно-желто-бурый лессовидный легкий суглинок, глыбистый, влажный, встречаются гумусовые пленки по граням и трещинам). Погребенная почва бурно вскипает от $\mathrm{HCl}$ (с горизонта B2ca). Гумусовый горизонт внешней насыпи вскипает слабо, внутренняя досыпка и конструкция из блоков не кипят.

Профиль погребенной почвы сильно перерыт землероями. Почва в целом имеет среднесуглинистый гранулометрический состав, небольшое облегчение наблюдается в верхнем горизонте. Гумусовый горизонт текстурно-дифференцирован, но морфологически солонцеватость выражена слабо. Количество ила в горизонте В1 по сравнению с A1 больше в 2 раза. Накопление глинистых частиц происходит в горизонтах В2са и ВСса. Содержание гумуса в гумусовом горизонте составляет 0,6-0,65 \%. Магнитная восприимчивость максимальна в горизонте A1 (117 n×10-5 единиц СИ). Почва вскипает с глубины 25 см, реакция среды вниз по профилю уменьшается от нейтральной до слабощелочной. Аккумуляция $\mathrm{CaCO}_{3}$ в виде белоглазки происходит в горизонте $\mathrm{BC}$ 'са $(9,6$ \%). Профиль почвы 
промыт от ЛРС и гипса. Погребенная почва диагностирована как темно-каштановая глубокозасоленная $\left(\right.$ K $\left.3^{\text {г3}}\right)$.

\section{Строение профиля и свойства современной почвы}

Разрез фоновой современной почвы (Ж-2-19) был заложен на залежном поле в 150 м к юго-востоку от кургана. Было проведено полевое описание морфологических свойств горизонтов почвенного разреза, выполнены полевые измерения магнитной восприимчивости. Химические и физико-химические свойства почвы представлены в таблице 2. Следует отметить, что почвенный покров района исследований полностью распахан, целинных степных участков практически не осталось. Растительный покров территории представлен, главным образом, полынными группировками с разнотравьем, встречаются отдельные куртины злаковых (Stipa capillata L, Festuca sulcata и др.). Общее проективное покрытие составляет 50-70\%.

Современная почва имеет следующее строение профиля: гор. А (0-10 см, частично восстановившийся верхний гумусовый горизонт, темно-коричнево-бурый легкий суглинок плитчато-комковатой структуры, уплотнен, влажноват; пронизан корнями, граница ровная, переход ясный по цвету и структуре); гор. $\mathrm{B}_{\text {пах }}$ (10-35 см, коричнево-бурый легкий суглинок, структура призмовидно-глыбистая, размер отдельностей 1-2 см, сухой, уплотнен; много корней, граница ровная, переход резкий по цвету и структуре); гор. В2са (белесо-темно-желто-бурый легкий суглинок, структура призмовидно-ореховатая, грани неровные, плотный, сухой, затеки гумуса по трещинам, карбонатная пропитка при подсыхании; граница ровная, переход ясный по формам выделения карбонатов); гор. ВСса (50-110 см, темно-желтобурый легкий суглинок, призмовидно-ореховатая сруктура, грани неровные, слабо отмыты с глинистыми кутанами, встречаются затеки и пленки гумуса, аккумуляция карбонатов в виде четко оформленной белоглазки размером около 2 см, сухой, плотный, граница неровная с редким проникновением белоглазки в нижележащей горизонт по корням растений); гор. С (110-180 см, темно-желто-бурый лессовидный легкий суглинок глыбистой структуры, влажный, плотный). Почва бурно вскипает от $\mathrm{HCl}$ (10 \%) с гор. В2са. Профиль разбит трещинами на глубину около 1 м, до глубины $60 \mathrm{~cm}$ встречаются крупные корни травянистой растительности.

Современная каштановая почва имеет среднесуглинистый гранулометрический состав, небольшое облегчение наблюдается с глубиной. Содержание гумуса не превышает $2 \%$ в пахотном горизонте и резко снижается до $0,18 \%$ в горизонте В2. Величина магнитной восприимчивости максимально в горизонте $\mathrm{B}_{\text {пах }}$, ниже ее значение составляет 47-

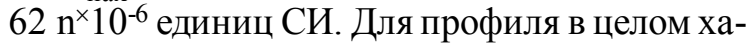
рактерна слабощелочная реакция ( $\mathrm{pH}$ изменяется от 8,3 до 8,7). Вскипание от $10 \% \mathrm{HCl}$ выражено с глубины 35 см. Содержание $\mathrm{CaCO}_{3}$ максимально в горизонте BCca, пахотный горизонт выщелочен от карбонатов, в материнской породе содержание карбонатов составляет 7,4 \%. Накопление ЛРС и гипса в почве не отмечено. Современная почва диагностирована как темно-каштановая глубокозасоленная $\left(\right.$ К $\left.3^{\text {г3}}\right)$.

\section{Почвенно-климатические условия и время сооружения кургана Жайык-1}

Рассмотрим свойства современной и погребенной почв кург. Жайык-1 (табл. 1-3). Основными характеристиками степных почв являются особенности гумусового и карбонатных профилей (мощности горизонтов, глубина вскипания, формы выделения новообразований карбонатов, содержание органического углерода, $\mathrm{CaCO}_{3}$ и др.), а также распределения по профилю легкорастворимых солей и гипса.

Погребенная и современная почвы диагностированы как темно-каштановые глубокозасоленные $\left(\right.$ К $\left.3^{\text {гз }}\right)$. Для них характерны хорошо выраженные гумусовые горизонты мощностью до 35 см, мощность гумусового горизонта современной почвы увеличена за счет припашки материала нижнего слоя. Величина магнитной восприимчивости в верхних горизонтах не превышает 114-117 и уменьшается к породе до 44-47 $\mathrm{n}^{\times} 10^{-6}$ единиц СИ. Горизонты аккумуляции карбонатов приурочены к средней части профиля и имеют призмовид- 
но-ореховатую структуру, новообразования представлены в виде хорошо оформленной белоглазки размером 1-2 см. Гумусовые горизонты промыты от карбонатов, почвы вскипают с глубины 25 см (гор. В2 са). Профили почв выщелочены от ЛРС и гипса. В погребенной почве в верхней части отмечается небольшое накопление диагенетических солей.

Таким образом, по сочетанию морфологических, магнитных, физико-химических и химических характеристик почвы имеют сходное строение профиля. Это дает основание сделать заключение, что природные условия во время сооружения кург. Жайык-1 в целом были аналогичны современным, в районе господствовали степные ландшафты с темно-каштановыми почвами.

Основной реконструируемой характеристикой палеоклиматических условий по данным археологических исследований является годовая сумма атмосферных осадков. На примере нижневолжских степей статистическими расчетами установлена прямая корреляция между величинами магнитных характеристик современных почв и среднегодовым количеством атмосферных осадков [Maher et. al., 2002, p. 1573]. По результатам многолетних почвенно-археологических исследований показано, что в погребенных почвах зафиксировалось состояние магнитного материала, равновесное палеоклиматическим условиям на момент сооружения насыпи археологического памятника [Алексеев и др., 2002, с. 58]. На основе этих данных были получены выводы об изменении атмосферной увлажненности Волго-Донского междуречья в эпоху раннего железного века [Демкин и др., 2012, рис. 1]. Учитывая то, что данные археологии определяют время сооружения кургана V-III вв. до н.э., и то, что за последние полвека в южной части степной зоны происходит направленное (примерно на 50 мм) увеличение годовых сумм осадков [Сажин, 1993, с. 44; Зайдельман и др., 1998; Тихонов, 2000 , с. 56; Сиротенко и др., 2007, с. 36], время сооружения кургана предположительно можно датировать V веком до н.э. Этап сооружения внутренней конструкции кургана (блочная насыпь с перекрытием и кольцевым рвом) и момент создания основной внешней насыпи разделяет некоторый временной период (до нескольких сотен лет). За это время начал восстанавливаться почвенный покров на первой грунтовой насыпи.

\section{ПРИМЕЧАНИЕ}

1 Работа выполнена за счет средств гранта РНФ 17-18-01406. Аналитический блок выполнен при поддержке РФФИ (грант 19-29-05178). Исследование проводилось в соответствии с Госзаданием 0191-2019-0046.

The work was supported by RSF (project no. 17-18-01406). The analytical block was completed supported by the RFBR (grant 19-29-05178). The research was carried out within with the state assignment 0191-2019-0046. 
M.V. Eltsov. Pedoarcheological Research of the Zhayyk-1 Kurgan

\section{ИЛЛЮСТРАЦИИ}

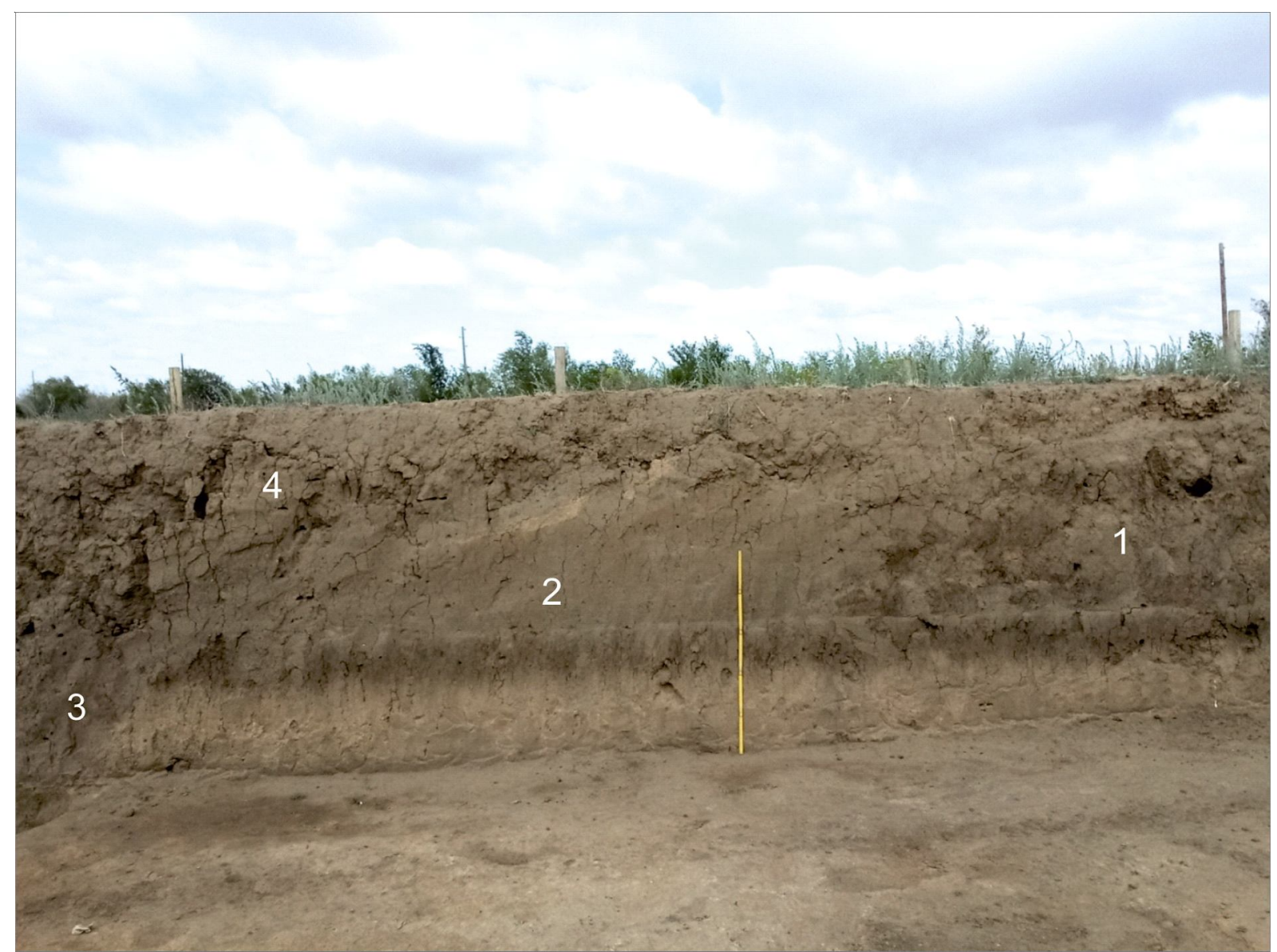

Рис. 1. Конструкционные особенности строения кургана (фотография автора):

1 - сооружение из гумусовых блоков; 2 - первая насыпь; 3 - кольцевой ров; 4 - вторая насыпь

Fig. 1. Construction features of the kurgan structure. Photo by the author:

1 - construction of humus blocks; 2 - the first mound; 3 - ring moat; 4 - the second mound

\section{Таблица 1. Свойства погребенной почвы кургана Жайык-1 (Ж-1-19)}

\section{Table 1. Properties of the buried soil of the Zhaiyk-1 kurgan (Zh-1-19)}

\begin{tabular}{|c|c|c|c|c|c|c|c|c|c|}
\hline \multirow{2}{*}{ Горизонт } & \multirow{2}{*}{$\begin{array}{c}\text { Глубина } \\
\text { (см) }\end{array}$} & \multirow{2}{*}{$\begin{array}{c}\text { Гумус } \\
(\%)\end{array}$} & \multirow{2}{*}{$\begin{array}{c}\mathrm{pH} \\
\text { водн. }\end{array}$} & \multirow{2}{*}{$\begin{array}{c}\mathrm{CaCO}_{3} \\
(\%)\end{array}$} & \multirow{2}{*}{$\begin{array}{c}\mathrm{CaSO}_{4} \\
(\%)\end{array}$} & \multirow{2}{*}{$\begin{array}{c}\text { Сумма } \\
\text { солей }(\%)\end{array}$} & \multirow{2}{*}{$\begin{array}{l}\text { МВ, } \mathrm{n}^{\times} 10^{-6} \\
\text { единиц СИ }\end{array}$} & \multicolumn{2}{|c|}{ Содержание фракций (\%) } \\
\hline & & & & & & & & $<0.001 \mathrm{MM}$ & $<0.01 \mathrm{MM}$ \\
\hline A1 & $0-10$ & 0,65 & 6,9 & 0,6 & 0,0 & 0,44 & 117 & 9 & 21 \\
\hline $\mathrm{B} 1$ & $10-25$ & 0,60 & 7,0 & 1,0 & 0,0 & 0,37 & 97 & 18 & 29 \\
\hline B2ca & $25-40$ & 0,44 & 8,1 & 5,7 & 0,0 & 0,37 & 79 & 21 & 38 \\
\hline BC'ca & $40-52$ & & 8,2 & 9,6 & 0,0 & 0,10 & 51 & 24 & 39 \\
\hline BC"ca & $52-105$ & & 8,5 & 4,2 & 0,1 & 0,10 & 44 & 15 & 24 \\
\hline Cca & $105-170$ & & 8,0 & 5,1 & 0,1 & 0,10 & 45 & 15 & 35 \\
\hline
\end{tabular}


M.В. Ельи̧ов. Почвенно-археологические исследования кургана Жайык-1

Таблица 2. Свойства фоновой современной почвы кургана Жайык-1 (Ж-2-19)

Table 2. Properties of the modern soil of the Zhaiyk-1 kurgan (Zh-2-19)

\begin{tabular}{|c|c|c|c|c|c|c|c|c|c|}
\hline \multirow{2}{*}{ Горизонт } & \multirow{2}{*}{$\begin{array}{c}\text { Глубина } \\
\text { (см) }\end{array}$} & \multirow{2}{*}{$\begin{array}{c}\text { Гумус } \\
(\%)\end{array}$} & \multirow{2}{*}{$\begin{array}{c}\mathrm{pH} \\
\text { водн. }\end{array}$} & \multirow{2}{*}{$\begin{array}{c}\mathrm{CaCO}_{3} \\
(\%)\end{array}$} & \multirow{2}{*}{$\begin{array}{c}\mathrm{CaSO}_{4} \\
(\%)\end{array}$} & \multirow{2}{*}{$\begin{array}{c}\text { Сумма } \\
\text { солей (\%) }\end{array}$} & \multirow{2}{*}{$\begin{array}{l}\mathrm{MB}, \mathrm{n}^{\times} 10^{-6} \\
\text { единиц СИ }\end{array}$} & \multicolumn{2}{|c|}{ Содержание фракций (\%): } \\
\hline & & & & & & & & $<0.001 \mathrm{MM}$ & $<0.01 \mathrm{MM}$ \\
\hline Апах & $0-10$ & 1,96 & 8,3 & 0,3 & 0,0 & 0,07 & 97 & 16 & 32 \\
\hline Впах & $10-35$ & 0,18 & 8,6 & 1,1 & 0,0 & 0,05 & 114 & 18 & 31 \\
\hline B2ca & $35-55$ & & 8,7 & 8,1 & 0,0 & 0,05 & 62 & 14 & 21 \\
\hline BCca & $55-110$ & & 8,6 & 8,7 & 0,0 & 0,05 & 45 & 17 & 38 \\
\hline $\mathrm{C}$ & $110-180$ & & 8,0 & 7,4 & 0,1 & 0,11 & 47 & 15 & 24 \\
\hline
\end{tabular}

\section{Таблииа 3. Морфологические и магнитные свойства почв кургана Жайык-1}

Table 3. Morphological and magnetic properties of soils of Zhaiyk-1 kurgan

\begin{tabular}{|c|c|c|}
\hline \multirow{2}{*}{ Показатели } & \multicolumn{2}{|c|}{ Разрез, время } \\
\hline & Ж-1-19, РЖВ & Ж-2-19, фон \\
\hline $\begin{array}{l}\text { Мощность гумусового горизонта: } \\
\text { А } \\
\text { А+B, см }\end{array}$ & $\begin{array}{l}10 \\
25\end{array}$ & $\begin{array}{l}10 \\
25\end{array}$ \\
\hline $\begin{array}{l}\text { Магнитная восприимчивость: } \\
\text { гор. А } \\
\text { гор. В1, } \\
\mathrm{n}^{\times} 10^{-6} \text { единиц СИ }\end{array}$ & $\begin{array}{c}117 \\
97\end{array}$ & $\begin{array}{c}97 \\
114\end{array}$ \\
\hline Глубина вскипания, см & 25 & 25 \\
\hline $\begin{array}{l}\text { Глубина залегания аккумуляции } \\
\text { карбонатов (гор. ВСса), см }\end{array}$ & 52 & 50 \\
\hline Мощность горизонта ВСса & 53 & 60 \\
\hline Новообразования карбонатов & Белоглазка & Белоглазка \\
\hline Средний размер белоглазки, мм & 10 & $10-20$ \\
\hline Почва & $\mathrm{K} 3^{\mathrm{\Gamma 3}}$ & $\mathrm{K} 3^{\mathrm{\Gamma 3}}$ \\
\hline
\end{tabular}

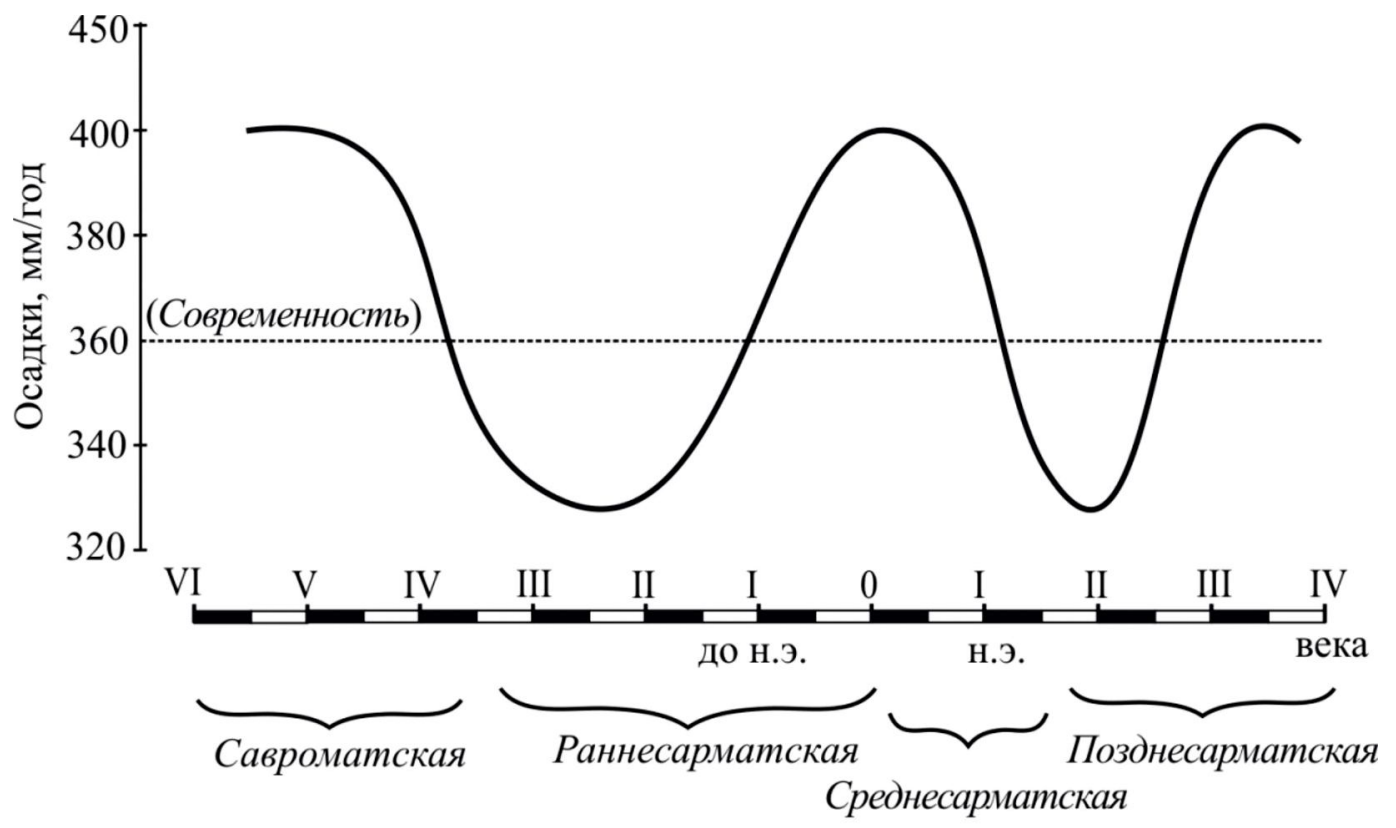

Археологические культуры

Рис. 2. Реконструкция динамики количества атмосферных осадков в сухостепной зоне Волго-Донского междуречья в савромато-сарматскую эпоху (по: [Демкин и др., 2012])

Fig. 2. Reconstruction of the dynamics of precipitation in the dry- steppe zone of the Volga-Don interfluve in the Sauromatian-Sarmatian epoch (after: [Demkin et al., 2012]) 


\section{СПИСОК ЛИТЕРАТУРЫ}

Алексеев А. О., Алексеева Т. В., Заварзина Д. Г., 2002. Роль железо-редуцирующих бактерий в формировании почвенного магнетита // Органическая минералогия : материалы I Российского совещания по органической минералогии. СПб. С. 55-59.

Аринушкина Е. В., 1970. Руководство по химическому анализу почв. М. : Изд-во МГУ. 490 с.

Геннадиев А. Н., 1990. Почвы и время: модели развития. М. : Изд-во МГУ. 232 с.

Демкин В. А., 1997. Почвоведение и археология. Пущино : ОНТИ НЦБИ АН СССР. 213 с.

Демкин В. А., Скрипкин А. С., Ельцов М. В., Золотарева Б. Н., Демкина Т. С., Хомугова Т. Э., Кузнецова Т. В., Удальцов С. Н., Каширская Н. Н., Плеханова Л. Н., 2012. Природная среда волго-уральских степей в савромато-сарматскую эпоху (VI в. до н.э. - IV в. н.э.). Пущино : ИФХиБПП РАН. 216 с.

Зайдельман Ф. Р., Тюльпанов В. И., Ангелов Е. Н., Давыдов А. И., 1998. Почвы мочарных ландшафтов формирование, агроэкология и мелиорация. М. : Изд-во МГУ. $180 \mathrm{c}$.

Роде А. А., 1984. Генезис почв и современные процессы почвообразования. М. : Наука. 130 с.

Сажин А. Н., 1993. Природно-климатический потенциал Волгоградской области. Научное исследование природно-климатических ресурсов области за 100-летний период. Волгоград : Изд-во Волгоградского сельскохозяйственного института. 86 с.

Сиротенко О. Д., Груза Г. В., Ранькова Э. Я., Абашина Е. В., Павлова В. Н., 2007. Современные климатические изменения теплообеспеченности, увлажненности и продуктивности агросферы России // Метеорология и гидрология. № 8. С. 34-38.

Таргульян В. О., Александровский А. Л., 1976. Эволюция почв в голоцене: (Проблемы, факты, гипотезы) // История биогеоценозов СССР в голоцене. М. : Наука. 123 с.

Тихонов В. Е., 2000. Ритмичность метеорологических факторов и биоклиматический потенциал в степной зоне Урала // Вопросы степеведения. Оренбург : Оренбургская губерния. С. 54-58.

Maher B. A., Alekseev A. O., Alekseeva T. V., 2002. Climate Dependence of Soil Magnetism Across the Russian Steppe: Significance for Use of Soil Magnetism as a Paleoclimatic Proxy // Quaternary Science Reviews. Vol. 21.P. $1571-1576$.

Procedures for Soil Analysis, 1995. Wageningen : International Soil Reference and Information Center. 364 p.

\section{REFERENCES}

Alekseev A.O., Alekseeva T.V., Zavarzina D.G., 2002. Rol' zhelezo-redutsiruyuschih bakteriy v formirovanii pochvennogo magnetita [Iron-reducing Bacteria Role in the Formation of Soil Magnetite].Organicheskaya mineralogiya: materialy I Rossiyskogo soveshhaniya poorganicheskoy mineralogii [Organic Mineralogy. Proceedings of the First Russian Conference on Organic Mineralogy]. Saint Petersburg, pp. 55-59.

Arinushkina E.V., 1970. Rukovodstvo po khimicheskomu analizu pochv [Guide to Chemical Analysis of Soils]. Moscow, MSU. 490 p.

Gennadiev A.N., 1990. Pochvy i vremya: modeli razvitiya [Soil and Time: Models of Development]. Moscow, MSU. $232 \mathrm{p}$.

Demkin V.A., 1997. Pochvovedenie i arkheologiya [Soil Science and Archaeology]. Pushchino, DSTI BRC USSR AS. 213 p.

Demkin V.A., Skripkin A.S., Eltsov M.V., Zolotareva B.N., Demkina T.S., Khomutova T.E., Kuznetszova T.V., Udal'tsov S.N., Kashirskaya N.N., Plekhanova L.N., 2012. Prirodnaya sreda volgo-ural'skih stepey v savromato-sarmatskuyu epohu (VI v. do n.e. - IV v. n.e.) [Natural Environment of the Volga-Ural Steppes in the Sauromatic-Sarmatian Epoch (VI century BC - IV century AD)]. Pushchino, IPBPSS. 216 p.

Zaydel'man F.R., Tyul'panov V.I., Angelov E.N., Davydov A.I., 1998. Pochvy mocharnyh landshaftov-formirovanie, agroekologiya i melioratsiya [Soils of Moist Landscapes- Formation, Agroecology and Melioration]. Moscow, MSU. 180 p.

Rode A.A.,1984. Genezis pochv i sovremennye processy pochvoobrazovaniya [Genesis of Soils and Modern Processes of Soil Formation]. Moscow, Nauka Publ. 130 p. 
Sazhin A.N.,1993. Prirodno-klimaticheskiy potentsial Volgogradskoy oblasti. Nauchnoe issledovanie prirodnoklimaticheskih resursov oblasti za 100-letniy period [Natural and Climatic Potential of the Volgograd Region. Scientific Research of Natural and Climatic Resources of the Region Over a 100-Year Period]. Volgograd, Volgograd Agricultural Institute. 86 p.

Sirotenko O.D., Gruza G.V., Ran'kova E.Ya., Abashina E.V., Pavlova V.N., 2007. Sovremennye klimaticheskie izmeneniya teploobespechennosti, uvlazhnennosti i produktivnosti agrosfery Rossii [Modern Climate Changes of Heat Supply, Humidity and Productivity of the Russian Agro-Sphere]. Meteorologiya $i$ gidrologiya [Meteorology and Hydrology], no. 8, pp. 34-38.

Targul'yan V.O., Aleksandrovskiy A.L., 1976. Evolyutsiya pochv v golotsene: (Problemy, fakty, gipotezy) [Evolution of Soils in the Holocene: (Problems, Facts, Hypotheses)]. Istoriya biogeotsenozov SSSR v golotsene [History of Biogeocenoses of the USSR in the Holocene]. Moscow, Nauka Publ. 123 p.

Tikhonov V.E., 2000. Ritmichnost' meteorologicheskikh faktorov i bioklimaticheskiy potentsial v stepnoy zony Urala [Rhythmicity of Meteorological Factors and Bioclimatic Potential in the Steppe Zone of the Urals]. Voprosy stepevedeniya [Questions of Steppe Studies]. Orenburg, Orenburgskaya guberniya Publ., pp. 54-58.

Maher B.A., Alekseev A.O., Alekseeva T.V., 2002. Climate Dependence of Soil Magnetism Across the Russian Steppe: Significance for Use of Soil Magnetism as a Paleoclimatic Proxy. Quaternary Science Reviews, vol. 21, pp. 1571-1576.

Procedures for Soil Analysis, 1995. Wageningen, International Soil Reference and Information Center. $364 \mathrm{p}$.

\section{Information About the Author}

Maxim V. Eltsov, Candidate of Sciences (Biology), Senior Researcher, Laboratory of Archaeological Soil Science, Institute of Physicachemical and Biological Problems in Soil Science of the Russian Academy of Sciences, Institutskaya St., 2, 142290 Pushchino, Russian Federation, m.v.eltsov@gmail.com, https://orcid.org/0000-0001-7886-8131

\section{Информация об авторе}

Максим Витальевич Ельцов, кандидат биологических наук, старший научный сотрудник лаборатории археологического почвоведения, Институт физико-химических и биологических проблем почвоведения РАН, ул. Институтская, 2, 142290 г. Пущино, Российская Федерация, m.v.eltsov@gmail.com, https://orcid.org/0000-0001-7886-8131 